\section{Analysis of Risk and Mispricing Hypotheses of Accruals: Evidence from Brazil}

\author{
Vinícius Gomes Martins ${ }^{1}$ \\ ${ }^{1}$ Federal University of Pernambuco, Postgraduate \\ Program in Accounting, Recife, Brazil \\ Paulo Aguiar do Monte ${ }^{2}$ \\ Márcio André Veras Machado ${ }^{2}$ \\ ${ }^{1}$ Universidade Federal da Paraíba, Postgraduate \\ Program in Accounting, Paraiba, Brazil
}

Received on:

04/22/2018

Approved on:

08/22/2018

\section{Responsible Editor:}

Prof. Dr. Javier Montoya del

Corte

Evaluation process:

Double Blind Review

\begin{abstract}
Purpose - Analyze how the accruals pricing is configured in the brazilian stock market, that is, if it represents a market mispricing or a risk factor.

Design/methodology/approach - We used a sample of nonfinancial companies listed in B3. To reach the objective, the portfolio methodology, asset pricing models were used, and two-stage crosssectional regression (2SCSR) was used to test risk and mispricing hypotheses.

Findings - The results obtained showed evidence of the accruals anomaly for the companies classified as small and that the evidence is stronger when evaluating the discretionary component. The two-stage cross-sectional regression analysis did not show that accruals represent a risk factor, suggesting that the evidence of anomaly obtained for discretionary accruals is caused by mispricing.

Originality/value - Non-rejection of the accruals' mispricing assumption leads to the conclusion that stock prices of small firms are influenced by the accounting results disclosed and that managers, by having capital market and profit incentives related, can use accounting choices opportunists with the motivation to maximize their expected utility, that is, to influence the price of shares through the distortions in profits.
\end{abstract}

Keywords - Accruals. Mispricing. Risk Factor

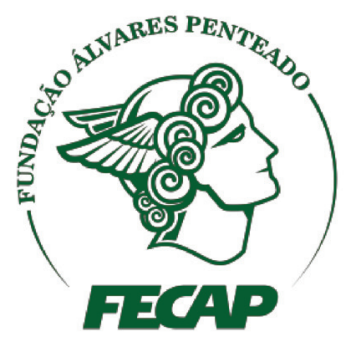

Review of Business Management

DOI: $10.7819 /$ rbgn.v21i1.3969 


\section{Introduction}

This study examines how the pricing of accruals is configured in the Brazilian market, that is, whether it represents market mispricing or a priceable risk factor. Following Hirshleifer, Hou, and Teoh (2012), two general approaches may be taken to explain accruals pricing, which was initially documented by Sloan (1996) in the North American market.

The first approach is related to low market sophistication or the market's limited ability to interpret and correctly price financial information, specifically profit, as initially demonstrated by Sloan (1996). Under this hypothesis, it is possible that companies that have high accruals levels provide financial information that leads to the incorrect pricing of their stock (mispricing). This approach is supported by the functional fixation hypothesis (FFH), according to which the market reacts to financial information regardless of whether this information affects the company's future cash flows or not (Tinic, 1990). This means that, according to this theory, investors and other users of financial information believe the profit disclosed to be accurate, without being concerned about the procedures used to measure it and without individually evaluating the components of that profit (Tinic, 1990).

Alternatively, the second approach takes into account (rational) asset pricing theories (Francis, Lafond, Olsson, \& Schipper, 2005). Under this approach, given the transient nature of accruals, especially discretionary accruals, and the possibility that they will not be realized in future cash flows, the profit reported by a company ultimately includes and involves a greater level of uncertainty for the market. This therefore requires a higher premium for the company's assets due to the perceived risk with respect to the uncertainty of future cash flows (Francis et al., 2005; Gray, Koh, \& Tong, 2009; Kim \& Ki, 2010).

In this rational asset pricing approach, higher average returns must be reflected for business portfolios defined according to the volume of accruals to compensate for the portfolio's risk. Under this hypothesis, the risk burden associated with the volume of a company's accruals can explain the relationship between accruals and the company's stock returns (Hirshleifer et al., 2012). This approach corroborates the efficient market hypothesis (EMH), which holds that the price of a traded stock continuously conveys, in a complete and instant manner, all relevant and available information with respect to that stock (Fama, 1970; 1991). Thus, under this approach, profit information, even the manipulated portion, is perceived and correctly priced.

In respect of these two approaches, one can see that correct accruals pricing depends on market characteristics. Therefore, despite the existence of international evidence regarding accruals mispricing and the risk factor, this evidence cannot be generalized to emerging or underdeveloped markets, as these markets are theoretically less efficient with regard to the pricing of public information (Lopes \& Walker, 2008). Moreover, the minority shareholder protection policies and corporate governance structures that ultimately facilitate earnings management practices are known to be weak in these markets (Porta, Lopez-de-Silanes, Shleifer, \& Vishny, 2002).

According to Haw, Ho, and Li (2011), in emerging markets, domestic investors are less sophisticated and more likely to focus on profit as a performance measure, without taking into consideration the information content of its components (accruals and cash flow). In such an environment, managers may have more incentive to engage in opportunistic earnings management practices that contribute to poor accruals pricing. Therefore, it seems appropriate to expand this evidence to these markets, such as the one in Brazil, a country which, according to the MSCI Emerging Markets Index, has emerging market characteristics.

The results of the few studies conducted with companies in the Brazilian market (Cupertino, Martinez, Jr., \& Costa, 2012; Takamatsu \& 
Fávero, 2013; Silva Filho \& Machado, 2013) all found weak evidence of the accruals anomaly. However, this study differs from these previous ones because, first, in addition to examining the mispricing hypothesis, it analyzes the competing hypothesis that accruals may represent a risk factor, making it impossible to obtain high returns without incurring additional risks (Francis et al., 2005). Furthermore, this study is distinguished by the fact that it considers the full International Financial Reporting Standards (IFRS) adoption period. According to Kaserer and Klingler (2008), an analysis of the accruals anomaly based on financial information prepared using the IFRS accounting model portrays this phenomenon more reliably. Rather than companies that adopt domestic standards, this anomaly appears to be driven mainly by companies that present their financial statements under IFRS or under the United States Generally Accepted Accounting Principles (US-GAAP). Kaserer and Klingler (2008) argue that as accounts based on the true and fair view, such as submissions based on the IFRS model, are difficult to verify, they may not be adequate in situations where there is a weak corporate governance system. Empirical evidence obtained by the authors for the German market has confirmed these arguments.

To achieve the proposed objective of this research, the portfolio formation methodology and multifactor asset pricing models were initially used. These facilitate an analysis of the evidence of total and discretionary accruals anomalies. Additionally, the relationship between accruals and returns was analyzed by means of individual assets (cross-sectional), using the panel data methodology. Finally, a two-stage regression (two-stage cross-sectional regression - 2SCSR) was used to test the risk factor and the mispricing hypotheses.

In relation to both the portfolio analysis and the individual asset methodology, the results show evidence of the accruals anomaly in companies with low market values (small) and that the evidence is strongest when evaluating the discretionary component, suggesting that this phenomenon is intensified by managers' discretionary decisions. The analysis using the two-stage regression methodology did not allow us to conclude that total and discretionary accruals represent a priceable risk factor, indicating that the anomaly is caused by market pricing errors (mispricing).

Failure to reject the accruals mispricing hypothesis in the Brazilian market corroborates the FFH, suggesting, given this set of information, that on average, investors are unsophisticated. This implies that the relationship between accounting profit and stock price is purely mechanical and that investors are systematically deceived by the accounting methods used and choices made by companies (Tinic, 1990). This evidence is important, as it highlights the possibility of company managers affecting the market by making accounting choices opportunistically, especially when there are incentives linked to the capital market.

In addition to this introduction, this study has four sections. The second section discusses the accruals risk and mispricing hypotheses; the third section presents the methods used to achieve the study objectives. The fourth section presents and discusses the empirical evidence obtained, and finally, the last section presents the conclusions, as well as the limitations of the study and suggestions for future research.

\section{Risk Factor and the Mispricing of Accruals}

Following the pioneering study by Sloan (1996), other studies have sought to investigate developments and possible explanations for the accruals anomaly. The literature offers two explanations for the relationship between accruals and stock returns. The first explanation holds that accruals represent a priceable risk factor and that this risk cannot be diversified (Francis et al., 2005; Chen, Dhaliwal, \& Trombley, 2008; Khan, 2008; Gray et al., 2009; Kim \& Ki, 2010; Mashruwala $\&$ Mashruwala, 2011). The second explanation 
suggests that the relationship between accruals and stock returns occurs due to market mispricing (Sloan, 1996; Lafond, 2005; Hirshleifer et al., 2012).

Informational risk derives from the imprecision of investor pay-off structure estimates based on available information (Easley \& O'Hara, 2004) or from information asymmetry between managers and investors with regard to capital investment decisions (Lambert, Leuz, \& Verrecchia, 2007). Both perspectives identify cash flows (or free cash flows) as being essential to the evaluation of such risk (Francis et al., 2005). Cash flows determine investor returns, whether in the form of dividends or capital gains; therefore, uncertainty in regard to cash flow is a source of informational risk, as explained by Easley and O'Hara (2004).

Based on these characterizations, it may be inferred that an unfavorable outcome for each profit attribute, experienced separately or together, creates a level of uncertainty regarding the generation of future cash flows and that this uncertainty stems mainly from the accruals component. In a multi-asset and multi-period environment with informed and uninformed investors, the information risk faced by uninformed investors is not diversifiable and therefore becomes priced (Easley \& O'Hara, 2004). This suggests that the required returns are affected by information risk, which is captured both by the extent of private information and by the accuracy of public and/or private information: more private information and less information accuracy lead to demands for higher returns due to the perceived incremental risk.

Using different representations of informational risk, empirical tests of the expected relationship between informational risk and stock returns have been conducted. For example, Botosan (1997) focused on disclosure scores, which were based on the amount of annual report information. Easley, Hvidkjaer, and O'Hara (2002) focused on information asymmetry between informed and uninformed traders and used insider trading probability scores (probability of informed trading - PIN), while Francis et al. (2005) focused on the quality of accruals. Each of these studies predicted and found a relationship between informational risk factors and stock returns.

Based on theoretical models (Easley \& O'Hara, 2004; Lambert et al., 2007), Francis et al. (2005) sought to show empirically that accruals represented a measure of informational risk. The authors evaluated whether the risk of uncertainty caused by the size of accruals affects the cost of capital of US companies and found that accruals quality is a priceable risk factor and plays a statistically and economically significant role in determining a company's equity capital cost.

Core et al. (2008) questioned Francis et al.'s results (2005), suggesting that their methodology (2005) did not allow us to infer that accruals quality represented a priceable risk factor. Using a two-stage cross-sectional regression model, Core et al. (2008) found no evidence that accruals represented a risk factor.

More recent studies have sought to establish better evidence as to whether accruals represent a risk factor. In the Australian market, Gray et al. (2009) examined the relationship between accruals quality and the cost of equity. Using the same tests as Francis et al. (2005) and Core et al. (2008), the authors provided consistent evidence that accruals represented a non-diversifiable risk factor and, therefore, affected the cost of equity of companies in the Australian market.

Using a sample of US companies, Kim and $\mathrm{Ki}$ (2010) analyzed whether the quality of profits, measured by the quality of accruals, affects the cost of equity. The authors used the same methodological approach as Core et al. (2008) but also included macroeconomic variables. They concluded that accruals quality represented a priceable risk factor. However, the authors also concluded that accruals represented 
a risk factor and that Core et al.'s (2008) evidence was significantly sensitive to relatively low stock returns.

Therefore, when considering accruals as a risk factor, abnormal returns must be associated with the corresponding risk levels to prevent the possibility of obtaining market advantages without incurring higher risk levels. On the other hand, according to the second explanation for the accruals anomaly, investors set profit objectives without taking into account the properties of the accruals and the cash flow components. This leads to stock pricing errors (mispricing) and to the possibility of obtaining abnormal returns without incurring the proportional risk levels (Sloan, 1996).

Xie's (2001) study separated total accruals into discretionary and nondiscretionary accruals and analyzed the existence of the mispricing of these components. The results showed that discretionary accruals are the main cause of the accruals anomaly. Xie's (2001) results are important because they suggest that managers' discretionary accounting choices may, in fact, be reflected in stock returns. Thus, if company management wishes to affect stock prices, due to the potential stock mispricing, one possible way of doing so is through discretionary accruals.

Using samples from 17 countries, LaFond (2005) conducted a study into the accruals anomaly. In order to evaluate whether institutional characteristics (legal regime and shareholder protection) were variables that affected the occurrence of this anomaly in the countries studied, he analyzed the implications of the subsequent returns of a trading strategy based on accruals. The author found strong evidence that the accruals anomaly is a global phenomenon and that no common factor among the countries analyzed explained it.

Using a new methodological approach, Ohlson and Bilinski (2015) analyzed the accruals risk and mispricing hypotheses. The authors intuited that high-risk stocks should experience high and low returns more frequently than lowrisk stocks. They found that low accruals increase the probability of high positive returns and reduce the probability of high negative returns. For Ohlson and Bilinski (2015), this finding is inconsistent with the view that accruals reflect risk and therefore supports the hypothesis that the accruals anomaly is truly explained by the mispricing hypothesis.

Some recent studies have been conducted in markets with the same characteristics as the Brazilian one, i.e., emerging or developing markets. Kim, Kim, Kwon, and Lee (2015) found evidence of the accruals anomaly in the South Korean stock market. After adjusting their sample for companies that showed losses, Ozkan and Kayali (2015) verified the presence of the accruals anomaly in the Turkish capital market. Additionally, using a trading strategy based on total accruals, the authors detected an $18.6 \%$ possibility of obtaining abnormal returns.

In the Brazilian context, compared to international evidence, evidence of the accruals anomaly is still incipient. More than 20 years after the publication of Sloan's study (1996), there is little evidence on the subject, with the notable exceptions of Cupertino, Martinez, and Costa Jr. (2012), Takamatsu and Fávero (2013), and Silva Filho and Machado (2013).

Using data from companies listed on the Brazilian stock market between 1990 and 2008, Cupertino et al.'s (2012) study was conducted according to Sloan's (1996) research. The results showed that the persistence of accruals was less than the persistence of cash flows; however, consistent evidence of the accruals anomaly was not found. Similarly, Takamatsu and Favero's (2013) and Silva Filho and Machado's (2013) findings confirm the weak evidence of the accruals anomaly in the Brazilian market. It should be stressed that these studies only examined the existence of the accruals anomaly and did not evaluate the competing hypothesis that accruals reflect risk. 


\section{Sample, Measurement, and Model Variables}

\section{I Portfolio Formation Methodology}

To evaluate the evidence of the accruals anomaly in different groups of companies, the portfolio method is used to formulate investment strategies based on total and discretionary accruals. Fama and French's (2008) methodology was used for the portfolio analysis. Specifically, at the end of June in each year, the stocks were sorted into ascending order according to the volume of accruals (total and discretionary) and distributed into quintiles. After ordering, the stocks were divided by their medians into two groups, Small and Big, according to the June market value. Finally, in June of each year, after the stocks had been ordered in this way, resulting from the intersection of the groups classified by accruals and size, ten portfolios were built ( $5 \times 2)$, which allowed us to evaluate the evidence of the anomaly for different company sizes. Weighted by market value, the return on each stock and the return on each portfolio were calculated on a monthly basis from July of year $t$ to June of year $t+1$.

In addition, we examined whether the returns obtained with the portfolio formation methodology continued to be consistent with the returns expected from the five-factor model (Liu, 2006; Machado \& Medeiros, 2011). The analysis was performed using Jensen's alpha, which is typically used to evaluate the abnormal return of a security or security portfolio. The evaluation involves observing whether the alphas of the calculated models are significantly different from zero. The non-statistical significance of the model alphas means that the returns of the portfolios formed on the basis of accruals are explained by the risk factors of the five-factor model.

Procedures used by Machado and Medeiros (2011) were adopted to obtain the fivefactor model risk factors (independent variables). Specifically, in June of each year, 16 portfolios were constructed that resulted from the intersection of two portfolios formed based on market value (Small and Big), two portfolios (Low and High) based on the book-to-market (BM) ratio, two portfolios based on time (Winners and Losers), and two portfolios based on liquidity (Low and High). Therefore, every month, the following calculations were made: the size factor was calculated as the difference between the average monthly returns of the Small portfolios and the average monthly returns of the Big portfolios; the BM factor was calculated as the difference between the average monthly returns of the High portfolios and the average monthly returns of the Low portfolios; the time factor was calculated as the difference between the average monthly returns of the Winners portfolios and the average monthly returns of the Losers portfolios; and the liquidity factor was calculated as the difference between the average monthly returns of the Low portfolios and the average monthly returns of the High portfolios. The market factor was calculated as the difference between the average, weighted by the value of each stock, of the monthly returns of all sample stocks and the risk-free rate, using the Special System of Custody and Liquidation of Federal Securities (Sistema Especial de Liquidação e Custodia - SELIC) reference rate as a proxy.

Note that the use of the Selic rate as a proxy for the risk-free rate is in line with previous studies (Rogers \& Securato, 2009; Machado \& Medeiros, 2011; Noda, Martelanc, \& Kayo, 2015; Machado, Faff, \& Silva, 2017; Machado \& Faff, 2018). However, as the Selic rate is not the same as a risk-free rate (zero volatility, zero default risk, and zero reinvestment risk), and as it is a historically high rate, the results for the excess returns and Jensen's alphas may be underestimated, which is a limitation of this research.

To ensure that the financial statements for the previous fiscal year were already disclosed and priced to avoid look-ahead bias, the portfolios were rebalanced in June of each year (Machado \& Medeiros, 2011). In Brazil, companies can disclose their standardized financial statements (SFS) by the end of the first quarter of the following year 
(end of March). However, due to uncertainties as to the Brazilian market efficiency, we decided to perform the balancing in June of each year, as according to the literature (Argolo, Leal, \& Almeida, 2012; Caldeira, Moura, \& Santos, 2013; Machado \& Medeiros, 2014; Machado, Faff, \& Silva, 2017). However, as many events that can potentially affect a security's market price may happen between early April and early June, this choice is a limitation of the study.

Portfolio returns (dependent variable) were obtained according to Fama and French's (2008) methodology, as described at the beginning of this section. For the portfolio analysis, as according to Machado and Medeiros's (2011) approach, we used the five-factor stock pricing model, as described by Equation 1 .

$$
E\left(R_{c, t}\right)-R_{f, t}=\alpha+\beta\left[E\left(R_{m, t}\right)-R_{f, t}\right]+\gamma(S M B)_{t}+\delta(H M L)_{t}+\omega(M O M)_{t}+v(L I Q)_{t}+\varepsilon_{t}
$$

where $\alpha$ is the Jensen's alpha of the portfolio, and $R_{c, t}$ represents the return on the portfolio in period t. $R_{f, t}$ is the risk free rate in period $\mathrm{t}, R_{c, t}-R_{f, t}$ represents the excess return on the portfolio in period $\mathrm{t}$, and $R_{m, t}$ is the market return in period t. $R_{m, t}-R_{f, t}$ represents the premium by market risk in period $\mathrm{t}, \mathrm{SMB}_{\mathrm{t}}$ is the premium of the size risk factor in period $t$, and $\mathrm{HML}_{\mathrm{t}}$ is the premium of the book-to-market risk factor in period t. TIM ${ }_{t}$ is the premium of the time risk factor in period $t, \mathrm{LIQ}_{\mathrm{t}}$ represents the premium of the liquidity risk factor in period $t$, and $\varepsilon_{t}$ is the regression error term.

The calculation of Equation 1 allowed us to analyze the ability of the five-factor model's risk factors to capture the accruals anomaly. In the event that the calculated alphas present statistical significance, it can be inferred that there is an abnormal return, suggesting that the portfolio returns are not explained by the models' risk factors. However, if the alphas do not show statistical significance, it can be inferred that the trading strategies based on accruals do not cause abnormal returns.

\subsection{Methodology for tests based on individual assets}

Through the use of a panel data methodology, the relationship between accruals and returns was analyzed in terms of individual assets (cross-sectional). Using this methodology and controlling for other determinants of the returns, the total and discretionary accrual coefficients were calculated to individually evaluate the relationship between accruals and returns. Equations 2 and 3 were thereby calculated.

$$
\begin{aligned}
& R_{i, t}=\alpha+\beta_{1, T} T A M_{i, t}+\beta_{2} B M_{i, t-1}+\beta_{3} M O M_{i, t}+\beta_{4} L I Q_{i, t}+\beta_{5} A C C_{i, t}+\varepsilon_{i, t} \\
& R_{i, t}=\alpha+\beta_{1} T A M_{i, t}+\beta_{2} B M_{i, t-1}+\beta_{3} M O M_{t}+\beta_{4} L I Q_{i, t}+\beta_{5} A D_{i, t}+\varepsilon_{i, t}
\end{aligned}
$$

where $R_{t}$ is the annual return of the stock of company $i$, in which the annual return is calculated from July of year $t$ to June of year $t+1$ and $A C C$ represents the total accruals of company $i$ in period t. $D A$ represents the discretionary accruals of company $i$ in period $t, S I Z$ represents 
size, measured as the natural logarithm of the market value of company $i$ in June of year $t$, and $B M$ is the natural logarithm of the book-to-market ratio of company $i$ in December of $t-1$. TIM is the time effect, represented by the accumulated stock return of company $i$ from July of year $t-1$ to June of year t. LIQ is market liquidity, measured as the average stock trading volume of company $i$ in period t. $\varepsilon_{t}$ is the regression error term of company $i$ in period $t$.

The calculation of Equation 2 yielded evidence of the size and sign of the relationship between total accruals and stock returns. Likewise, Equation 3 identified the size and direction of the relationship between discretionary accruals and stock returns. If the signs of these variables are negative and significant, then it may be concluded that there is evidence of the accruals anomaly.

The hypothesis that the variance of residuals reflecting individual differences would be equal to zero (random effect) and the hypothesis that the intercepts would be equal for all cross sections (fixed effect) were rejected for both samples, suggesting therefore that the most appropriate model for the data set used in the equations is Pooled Ordinary Least Squares (POLS). Equations 2 and 3 were therefore calculated using POLS panel data.

\subsection{Two-stage regression methodology}

According to Core et al. (2008), the appropriate method to test whether a given risk factor is reflected in a price is the two-stage regression (two-stage cross-sectional regression - 2SCSR). This method provides a test of the hypothesis that a certain proposed risk factor explains the cross-sectional variation of expected returns. To apply the two-stage regression technique, portfolios were also formed according to Fama and French's (2015) methodology, with the inclusion of an accruals factor in place of the asset growth factor. This can occur as these two variables are correlated, as documented by Cooper, Gulen, and Schill (2008).

To obtain the (total and discretionary) accruals factors, in June of each year, 16 portfolios were constructed resulting from the intersection of the following: a) two portfolios based on accruals (Low and High); b) two portfolios based on market value (Small and Big); c) two portfolios based on the book-to-market ratio (Low and High); d) two portfolios based on profitability (Low and High); and e) two portfolios based on liquidity (Low and High). Other factors were calculated as follows: i) the size factor was calculated monthly as the difference between the average monthly returns of Small and Big portfolios; ii) the book-to-market factor was calculated as the difference between the average monthly returns of the High and Low portfolios; iii) the profitability factor was calculated as the difference between the average monthly returns of the Low and High portfolios; and iv) the market factor was calculated as the difference between the average, weighted by the value of each stock, of the monthly return of all stocks in the sample and the risk-free rate, for which the Selic rate was adopted as a proxy. To ensure that the financial statements for the previous fiscal year were already disclosed and priced to avoid look-ahead bias, the portfolios were rebalanced in June of each year (Machado \& Medeiros, 2011).

For the econometric approach, Core et al.'s (2008) study was followed. In the first stage, using Fama and French's (2015) model, the betas of the portfolios were calculated by a time series regression with the inclusion of the (total and discretionary) accruals factor, as shown in Equation 4.

$$
\begin{aligned}
& R_{p, t}-R_{f, t}=\alpha+\beta_{p, m e r c}\left(R_{m, t}-R_{f, t}\right)+\beta_{p, p t} S M B_{t}+\beta_{p, p b m} H M L_{t}+\beta_{p, r e n t} R E N T_{t}+ \\
& \beta_{P, a c} \text { ACfator } \text { fat }_{t}
\end{aligned}
$$


where $R_{p, t}$ represents the return on portfolio $p$ in month $t(20(2 \times 2 \times 5)$ portfolios were considered, based on the interaction of accruals (5 portfolios), size ( 2 portfolios), and book-tomarket ( 2 portfolios)). $R_{f, t}$ is the risk-free rate in month $t, R_{m, t}$ is the market return in month $t$, and $S M B_{t}$ is the premium of the size risk factor in period t. HML $L_{t}$ is the premium of the bookto-market risk factor in period $t, P R O F_{t}$ is the premium of the profitability factor in period $t$, and $A C$ is the premium based on the accruals factor. $\varepsilon_{t}$ represents the regression error term.

In the second stage, the risk factor premiums were calculated. For this, the betas calculated in Equation 4 were used and regressed in a cross-section with the average excess returns, as in Equation 5:

$$
R_{p, t}-R_{f, t}=\lambda_{0}+\lambda_{1} \hat{\beta}_{p, m e r c}+\lambda_{2} \hat{\beta}_{p, p t}+\lambda_{3} \hat{\beta}_{p, p b m}+\lambda_{4} \hat{\beta}_{p, p r e n t}+\lambda_{5} \hat{\beta}_{p, a c}+v_{c}
$$

where $R_{p, t}-R_{f, t}$ :equals the average excess returns of the period analyzed. $\hat{\beta}_{p, \text { merc }}, \hat{\beta}_{p, p t}$, and $\hat{\beta}_{p, p b m}, \hat{\beta}_{p, p r e n t} e \hat{\beta}_{p, a c}$ are parameters calculated in stage 1 (Equation 4 ). $\lambda_{1}, \lambda_{2}, \lambda_{3}, \lambda_{4}$, and $\lambda_{5}$ represent the risk factor premiums, where $\lambda_{5}$ is the coefficient of interest of the study. is the regression error term.

As the independent variables of Equation 5 are regressors calculated using Equation 4, the standard error may be underestimated. Therefore, the standard error was corrected by the factor $\left(1+\hat{\lambda}^{\prime} \hat{\Sigma}_{f}^{-1} \hat{\lambda}\right)^{-1}$, where $\hat{\Sigma}_{f}$ is the covariance matrix of the factors size, book-to-market, profitability, and accruals, and is the matrix of the calculated parameters. Thus, if coefficient $\lambda_{5}$ has statistical significance and a positive sign, then it can be inferred that the accruals represent a priceable risk factor that affects a company's cost of equity.

\subsection{Research variables}

To calculate total accruals, the cash flow approach was used. Equation 6 shows the calculation of total accruals:

$$
A T_{i, t}=\frac{\text { Lucro }_{i, t}-\mathrm{FCO}_{i, t}}{A_{i, t-1}}
$$

where $T A_{i, t}$ represents the total accruals of company $i$ in period $t$. Profit, ${ }_{, t}$ equals the results before extraordinary items and discontinued operations of company $i$ between the years $t-1$ and t. $O C F_{i, t}$ is the operational cash flow of company $i$ between periods $t$ and $t$. $A_{i, t-1}$ represents the total assets of company $i$ in period $t-1$.

The model proposed by Pae (2005) was chosen for the calculation of discretionary accruals. Pae's (2005) model provides an updated version of Jones' (1991) model, which, in turn, was the model used by the pioneering studies that addressed the accruals anomaly (Sloan, 1996; Xie, 2001) and is also one of the most widespread models in the empirical literature on management (Dechow, Hutton, Kim, \& Sloan, 2012). Pae's (2005) model offers a development relative to Jones' (1991): it includes a variable representing cash flow and a variable that captures the natural reversal of past accruals in the current period. Pae's (2005) model is represented by Equation 7.

$$
A T_{t}=\alpha\left(\frac{1}{A_{t-1}}\right)+\alpha_{1}\left(\Delta R_{t}\right)+\alpha_{2}\left(P P E_{t}\right)+\alpha_{3}\left(F C O_{t}\right)+\alpha_{4}\left(F C O_{t-1}\right)+\alpha_{5}\left(A T_{t-1}\right)+\varepsilon_{t}
$$


where TA represents the total accruals in period $t$, weighted by the total assets at the end of period $t-1 . \mathrm{A}_{\mathrm{t}-1}$ represents the total assets at the end of period $t-1$, and $\Delta \mathrm{R}_{\mathrm{t}}$ is the variation in net revenue between periods $t-1$ and $t$, weighted by the total assets at the end of period $t-1$. PPE $_{\mathrm{t}}$ represents the balance of immobilized assets, intangible assets, and deferred assets accounts in period $t$, weighted by the total assets at the end of period $t-1 . \mathrm{OCF}_{\mathrm{t}}$ is the operational cash flow at the end of period $t$, weighted by the total assets at the end of period $t-1$, and $\mathrm{OCF}_{\mathrm{t}-1}$ is the operational cash flow at the end of period $\mathrm{t}-1$, weighted by the total assets at the end of period $t-2$. $T A_{t-1}$ represents the total accruals in period $t-1$, weighted by the total assets at the end of period $t-2 . \varepsilon_{\mathrm{t}}$ is the regression error term.

Total accruals, the dependent variable of Pae's (2005) model, can be divided into those accruals that are discretionary and those that are nondiscretionary. While nondiscretionary accruals are explained by the model's independent variables, the discretionary accruals are obtained from the regression error (residue). Thus, the closer to 0 (zero) the error is, the lower the discretionary accruals (proxy for results manipulation). Similarly, the further away from 0 (zero) the error is, regardless of the direction, the greater the evidence of results manipulation.

Cross-sectional estimates were performed to calculate discretionary accruals; however, this was done for each year by separating the sample by economic sector, as companies belonging to the same economic sector tend to exhibit similar accruals behavior (Pae, 2005).

Stock returns were calculated by continuous capitalization in logarithmic form, and the return on portfolios was calculated by the return weighted by value. The book-to-market ratio was calculated by dividing the accounting value by the net asset market value. Market liquidity was obtained using the traded volume, as recommended by Machado and Medeiros (2011). Finally, as according to Fama and French (2015), the profitability measure used was return on assets (ROA), which was obtained by dividing the EBIT (Earnings Before Interest and Taxes) of period $t$ by the operating assets of $t-1$.

\subsection{Data and sample}

The population of this research comprised all the stocks of nonfinancial companies listed on the Stock, Commodities, and Futures Exchange of São Paulo (Bolsa de Valores, Mercadorias e Futuros de São Paulo - BM\&F Bovespa) in the 2010-2014 period. The year 2010 was chosen as the starting year because it coincided with the full adoption of international accounting standards and due to the availability of some of the variables used in this research. Although the use of periods prior to 2010 would have provided a larger sample, these periods could have significant and difficult-to-control disadvantages, such as the fact that accounting number changes during those periods could not only occur due to economic events but also due to regulatory changes, which could significantly affect total and discretionary accruals estimates.

Financial companies were not considered because they belong to a very specific sector with particular characteristics, such as a high level of leverage and differentiated asset structure, which can distort accounting results, especially the calculation of accruals.

The sample used was non-probabilistic, and therefore companies were excluded for the following reasons: the information required to calculate the variables considered in the study were not provided by or available for the company; the company had negative equity, which would affect the calculation of some variables, such as the book-to-market ratio; the company's consecutive monthly stock prices for the 12 months following the date of portfolio formation, which was required to calculate the stock return, was not available. Finally, the data used in the study were extracted from Thomson Reuters Eikon and the BM\&FBOVESPA website. 


\section{Presentation and Discussion of Results}

The sample used for the portfolio methodology represented, on average, 52\% of the number of companies listed on the BM\&FBovespa in the period from 2010 to 2014 . The analysis began in 2011, as the year 2010 was used to calculate the time factor and the bookto-market ratio.

For the portfolio methodology, 830 observations were analyzed. Regarding the analysis of the individual assets, for this methodology, as all of the information was not available, the sample was smaller, i.e., 706 observations were included. Note that while there were a small number of listed companies and problems with missing data (missing values), this limitation is characteristic of research on the Brazilian market. Therefore, the size of the sample studied is one of the limitations of this research.

Table 1 shows the results obtained using the portfolio methodology. Considering all the companies, the formulated strategy revealed a positive spread for both total (0.018) and discretionary (0.019) accruals, demonstrating that the average return of the portfolios based on stocks that presented lower accruals volumes (Low) was superior to the returns of the portfolios with a higher volume of accruals (High); however, this difference was not significantly different from zero. Note that when considering all the companies, the spread obtained for the strategy formulated on the basis of discretionary accruals was higher than that obtained for the strategy formulated on the basis of total accruals, suggesting that treating the managerial discretion effect separately produces a stronger result than that produced when it is treated in conjunction with nondiscretionary accruals.

To evaluate whether the accruals effect is different for different company sizes, a control was performed for size, segregating the portfolios into Big and Small based on market value. It can be observed from Panel A of Table 1 that the accruals anomaly appears to exist for companies with lower market values, as the average monthly return of the Low portfolios was positive and greater than the return of the High portfolios. Moreover, it was significant at the 5\% and $10 \%$ level for total and discretionary accruals, respectively. This evidence supports the findings of Mashruwala, Rajagopal, and Shevlin (2006), who observed that the accruals anomaly is concentrated in smaller stocks.

Analyzing the spread of the average monthly returns of portfolios based on discretionary accruals for Small portfolios, it can be seen in Panel A that the spread of the average monthly returns for Small portfolios with discretionary accruals is superior to the spread obtained from Small portfolios based on total accruals, by $1.7 \%$ (0.082 compared to 0.065$)$. These results corroborate similar evidence obtained when considering all the companies and confirm Xie's (2001) findings that concluded that the accruals anomaly is caused mostly by the discretionary component.

Panel B shows evidence of the accruals effect after controlling for risk factors, as used by Machado and Medeiros (2011). This analysis was performed to ascertain whether the evidence obtained in the portfolios analysis (Panel A) persisted after controlling for risk factors. To this end, Jensen's alphas were calculated for the pricing models for the portfolios formed based on total and discretionary accruals. If the alphas of the models were not statistically equal to zero, it would mean that the risk factors failed to explain the returns, thereby suggesting that there was a marginal return or an anomaly.

Table 1, Panel B shows that for portfolios based on discretionary accruals and considering all the companies, only the alpha of the second portfolio (C2) was statistically significant (-0.011). This indicates that the five-factor model did not fail to explain the accruals effect, considering the portfolios for all the companies; this in turn suggests that the returns obtained for portfolios based on discretionary accruals (Panel A) are not abnormal returns. However, when 
controlling for size, it can be observed that the alpha of small businesses (Small portfolios), with a low volume of total and discretionary accruals
(Low), is significantly different from zero (at the $10 \%$ level), leading to positive and significant spreads.

Table 1

Return of portfolios constructed based on total and discretionary accruals with and without controlling for size and risk factors

Panel A - Returns without controlling for risk factors

\begin{tabular}{|c|c|c|c|c|c|c|c|}
\hline \multirow[b]{2}{*}{ Accruals } & \multirow[b]{2}{*}{ Size } & \multicolumn{5}{|c|}{ Portfolio distribution } & \multirow[b]{2}{*}{ Spread } \\
\hline & & $\begin{array}{c}\text { High } \\
\text { (C1) }\end{array}$ & $\mathrm{C} 2$ & C3 & $\mathrm{C} 4$ & $\begin{array}{l}\text { Low } \\
\text { (C5) }\end{array}$ & \\
\hline \multirow{2}{*}{ Totais } & All & $-0,011$ & $-0,002$ & 0,001 & $-0,009$ & 0,007 & 0,018 \\
\hline & Big & $-0,002$ & 0,005 & 0,010 & 0,001 & 0,003 & 0,092 \\
\hline \multirow{4}{*}{ Discretionary } & Small & $-0,008$ & 0,005 & $-0,008$ & 0,001 & $0,028^{* *}$ & $0,065^{*}$ \\
\hline & All & $-0,011$ & $-0,013$ & 0,001 & 0,001 & 0,008 & 0,019 \\
\hline & Big & $-0,003$ & $-0,005$ & 0,009 & 0,010 & 0,002 & 0,005 \\
\hline & Small & $-0,007$ & $-0,014$ & 0,004 & $0,019^{* *}$ & $0,025^{*}$ & $0,082^{*}$ \\
\hline
\end{tabular}

Panel B - Returns when controlling for risk factor

\begin{tabular}{|c|c|c|c|c|c|c|c|}
\hline \multirow[b]{2}{*}{ Accruals } & \multirow[b]{2}{*}{ Size } & \multicolumn{5}{|c|}{ Portfolio distribution } & \multirow[b]{2}{*}{ Spread } \\
\hline & & $\begin{array}{c}\text { High } \\
\text { (C1) }\end{array}$ & $\mathrm{C} 2$ & $\mathrm{C} 3$ & $\mathrm{C} 4$ & $\begin{array}{l}\text { Low } \\
\text { (C5) }\end{array}$ & \\
\hline & All & $-0,005$ & 0,001 & 0,003 & $-0,002$ & 0,001 & 0,018 \\
\hline Totais & Big & 0,002 & $0,008^{*}$ & $0,011^{*}$ & $-0,006$ & 0,012 & 0,092 \\
\hline \multirow{4}{*}{ Discretionary } & Small & 0,018 & $0,018^{* *}$ & 0,006 & 0,005 & $0,019^{*}$ & $0,065^{*}$ \\
\hline & All & $-0,004$ & $-0,011^{* *}$ & 0,001 & 0,002 & 0,006 & 0,019 \\
\hline & Big & 0,004 & $-0,002$ & 0,008 & $0,011^{* * *}$ & $0,016^{*}$ & 0,005 \\
\hline & Small & $-0,002$ & $-0,016$ & $0,018^{* * *}$ & 0,005 & $0,019^{* *}$ & $0,082^{*}$ \\
\hline
\end{tabular}

* Significant at $10 \%$. ** Significant at 5\%. *** Significant at $1 \%$.

To evaluate whether total and discretionary accruals separately affect stock returns, after controlling for other determinants, an analysis was performed with individual assets, using the calculation of Equations 2 and 3. Table 2 shows the results of model calculations for the sample with all the companies. This shows that the book-to-market, time, and discretionary accruals variables are statistically significant in explaining stock returns. This means that the discretionary accruals variable affects stock returns separately, even after controlling for other determinants of stock returns. Their negative coefficient (-0.029) confirms the evidence obtained from the portfolio methodology that indicates the accruals anomaly is caused mainly by the discretionary accruals component.

These findings are similar to those obtained by Xie (2001) and Chan et al. (2001). However, they run counter to those obtained by Cupertino et al. (2012), who found that discretionary accruals did not affect the accruals anomaly. The evidence from Cupertino et al.'s (2012) study was obtained using other methods, and their study was conducted in a period prior to that contemplated by this research. Thus, these differences in results can be explained by the analysis period, the companies in the sample, and the full adoption of international accounting standards. According to Kaserer and 
Klingler, the latter is important (2008) because an accounting model based on the true and fair view can facilitate managerial discretion and reduce the verifiability of accounting information, consequently contributing to the appearance of poor accruals pricing.

Table 2

Results of panel data models (POLS) for analysis of individual assets, considering all companies from 2010 to 2014

\begin{tabular}{|c|c|c|c|c|}
\hline \multirow{3}{*}{ Description } & \multicolumn{4}{|c|}{ All Companies } \\
\hline & \multicolumn{2}{|c|}{ Total Accruals } & \multicolumn{2}{|c|}{ Discretionary Accruals } \\
\hline & Coefficient & p-value & Coefficient & p-value \\
\hline Size & 0.001 & 0.597 & 0.000 & 0.398 \\
\hline Book-to-market & -0.082 & 0.000 & -0.079 & 0.000 \\
\hline Time & 0.615 & 0.000 & 0.625 & 0.000 \\
\hline Liquidity & -0.001 & 0.514 & -0.001 & 0.314 \\
\hline Total Accruals & 0.001 & 0.222 & - & - \\
\hline Discretionary Accruals & - & - & -0.029 & 0.000 \\
\hline Constant & -0.025 & 0.376 & -0.033 & 0.295 \\
\hline Adjusted $\mathrm{R}^{2}$ & \multicolumn{2}{|c|}{0.387} & \multicolumn{2}{|c|}{0.407} \\
\hline $\mathrm{F}$ test & \multicolumn{2}{|c|}{0.000} & \multicolumn{2}{|c|}{0.000} \\
\hline Ramsey RESET ${ }^{a}$ & \multicolumn{2}{|c|}{0.564} & \multicolumn{2}{|c|}{0.453} \\
\hline Durbin-Watson ${ }^{\mathrm{b}}$ & \multicolumn{2}{|c|}{2.004} & \multicolumn{2}{|c|}{1.897} \\
\hline White test ${ }^{c}$ & \multicolumn{2}{|c|}{0.000} & \multicolumn{2}{|c|}{0.000} \\
\hline Jarque-Bera $^{\mathrm{d}}$ & \multicolumn{2}{|c|}{0.000} & \multicolumn{2}{|c|}{0.000} \\
\hline Observations & \multicolumn{2}{|c|}{478} & \multicolumn{2}{|c|}{478} \\
\hline
\end{tabular}

a The hypothesis of the existence of omitted relevant variables (specification error) is rejected.

b The hypothesis of residuals autocorrelation is rejected.

c Standard errors are calculated with a correction for White's heteroscedasticity, since the null hypothesis of homoscedastic variances was rejected at the $5 \%$ level. The hypothesis of multicollinearity was rejected, as all variables had a variance inflation factor (VIF) statistic of less than 10 (GUJARATI, 2011).

$\mathrm{d}$ According to the central limit theorem and considering that 478 observations were used, the assumption of normality can be relaxed (BROOKS, 2002). Furthermore, as the parameters will not be used to make predictions (inferences), the implications of the non-normal distribution of the residuals in the $\mathrm{F}$ and $\mathrm{t}$ tests can be relaxed (GUJARATI, 2011). Finally, White's correction increases the standard error, decreasing the $t$ statistics, and making its calculation more robust.

As some evidence of the accruals anomaly has been found, especially in relation to discretionary accruals, potential explanations for this evidence will now be considered. There are two approaches in the literature that can be used to explain the documented accruals anomaly: 1) The information causes mispricing, as the market is not sophisticated enough to interpret and correctly price the implications of current accruals, particularly discretionary accruals, for future results; 2) Accruals represent a risk factor due to their transient nature and the possibility of nonperformance in future cash flows. This is especially true of discretionary accruals, in which the profit reported by companies incorporates and provides a higher level of uncertainty for the market (when sophisticated), therefore requiring a higher perceived risk premium derived from the uncertainty of future cash flows. 
In accordance with Core et al.'s (2008) study, a two-stage regression model was used to test the abovementioned approaches. The first stage calculated the betas of the risk factors in the time series, and the second calculated the premiums of the risk factors, using cross-sectional regressions. Table 3 shows the regression results for the second stage of the methodology: the objective in this stage was to evaluate whether the total and discretionary accruals represented priceable risk factors. To summarize, the average excess return in the period analyzed $\left(R_{p, t}-R_{f, t}\right)$ was used for the second stage, and the betas calculated in the first stage were used as independent variables.

Table 3 shows that the premiums for the total and discretionary accrual risk factors, shown in Table 3 as $\lambda 5$, were negative, which means that there is no evidence that total and discretionary accruals represent a risk factor, as the betas of the accruals factors obtained in the first stage were negatively related to the average excess returns. This means that the portfolios of companies with low accruals volumes tend to have larger returns than the portfolios formed by companies with high accruals volumes. This evidence thus confirms the results obtained and suggests that the accruals anomaly is possibly caused by mispricing. This corroborates the evidence obtained by Ohlson and Bilinski (2015), whose results were inconsistent with the view that accruals reflect risk and which support the hypothesis that the accruals anomaly is truly caused by mispricing.

Table 3

Results of the second stage of the regressions evaluating evidence of an accruals risk factor - 20102014

\begin{tabular}{|c|c|c|c|c|c|c|c|c|}
\hline \multirow{2}{*}{ Accruals } & & \multicolumn{6}{|c|}{ Risk factor premium } & \multirow{2}{*}{$\begin{array}{c}\mathbf{R}^{\mathbf{2}} \\
\text { Adjust. }\end{array}$} \\
\hline & & $\lambda$ & $\lambda 1$ & $\lambda 2$ & $\lambda 3$ & $\lambda 4$ & $\lambda 5$ & \\
\hline \multirow{2}{*}{ Totais } & Coef. & 0,019 & $-0,024$ & $-0,013$ & $-0,011$ & 0,005 & $-0,007$ & \multirow{2}{*}{0,686} \\
\hline & t Shanken & $2,547^{* * *}$ & $-2,800^{* * *}$ & $-2,337^{* * *}$ & $-2,130^{* *}$ & 0,968 & $-3,017^{* * *}$ & \\
\hline \multirow{2}{*}{ Discretionary } & Coef. & 0,015 & $-0,022$ & $-0,010$ & $-0,013$ & 0,007 & $-0,004$ & \multirow{2}{*}{0,586} \\
\hline & t Shanken & $1,579^{*}$ & $-2,649^{* * *}$ & $-2,052^{* *}$ & $-2,748^{* * *}$ & $1,712^{* *}$ & $-0,878$ & \\
\hline
\end{tabular}

* Significant at $10 \%$; ${ }^{* *}$ Significant at $5 \%$. ${ }^{* *}$ Significant at $1 \% ; \lambda={ }_{1}$ market risk factor premium; $\lambda_{2}=$ size risk factor premium; $\lambda_{3}=$ book-to-market risk factor premium; $\lambda_{4}=$ profitability risk factor premium; and $\lambda_{5}=$ accruals risk factor premium.

Regarding this set of information relating to accruals, note that if managers make opportunistic accounting choices in order to affect stock prices, they will not be punished with higher funding costs, as the results show that the market, on average, is not sophisticated. In contrast, the results indicate that the market does not correctly price information relating to discretionary accruals, suggesting that if managers have incentives linked to the company's performance in the capital market, they may be successful with respect to profit measurements, by trying to manipulate the stock price using their managerial discretion.

\section{Concluding Remarks}

Supported by the extended functional fixation and efficient market theories, this research set out to evaluate the way in which accruals pricing is configured in the Brazilian market, that is, whether it represents market mispricing or a priceable risk factor.

The evidence obtained using the portfolio methodology showed evidence of the accruals anomaly for companies classified as small, and that evidence was stronger when evaluating the discretionary component. Furthermore, the fivefactor model proposed by Machado and Medeiros 
(2011) failed to explain the small businesses' portfolio returns, suggesting that even when risk-adjusted, it was possible to obtain positive and different-from-zero returns. The results were more consistent for portfolios based on the discretionary accruals component.

Providing evidence that the anomaly obtained for discretionary accruals is caused by market pricing errors (mispricing), an analysis using the two-stage regression methodology did not allow us to conclude that total and discretionary accruals represent a priceable risk factor. In summary, it was concluded that the evidence of accruals pricing can be identified as market mispricing and that this evidence is directly related to the discretionary component of profits. Additionally, this anomaly is seen more consistently in companies with low market values.

Therefore, these results suggest that by using discretionary accruals, managers can succeed when trying to affect the market, as this information on accruals can lead investors to make pricing errors (mispricing). These results therefore suggest that the local market, on average, is not sophisticated and that the discretionary portion of profit is not highly likely to turn into future cash flows, leading to poor profit pricing.

The non-rejection of the accruals mispricing hypothesis leads to the conclusion that small business stock prices are affected by the accounting results disclosed (Sloan, 1996; Francis et al., 2005) and that managers with incentives linked to the capital market (Martinez, 2001) and profit-linked incentives (Fields et al., 2001) can make opportunistic accounting choices in order to maximize their expected utility, affecting the stock price by the distortions in profits.

This research has some limitations in its methodological implementation, including the following: i) the choice of the portfolio rebalancing period (June) and ii) the proxy used for the risk-free rate (SELIC). The first limitation arises from the fact that, in Brazil, companies are obliged to disclose their financial figures by the end of the first quarter (end of March). There are therefore at least two more months of information that may have affected the results, during which time other events could have happened; therefore, depending on the Brazilian market's efficiency, the results of the portfolio formation methodology may have been affected. Thus, future studies could focus on a different rebalancing period (ending in late March or April) in order to expand the debate and scope of this study. In regard to the second limitation, it should be emphasized that the Selic rate may not meet the requirements of a risk-free rate. However, as the Selic rate is a relatively high rate, some results, for example, excess returns and Jensen's alpha, may be underestimated.

It should be noted that the results cannot be generalized to the entire Brazilian market and are limited to the companies studied, as the sampling process used was not probabilistic. An expansion of the study sample and the inclusion of data from other developing countries could therefore provide a significant contribution, as this might reveal whether the results of this research are specific to the Brazilian market or can be generalized to other markets with similar characteristics.

\section{References}

Argolo, E. F. B., Leal, R. P. C., \& Almeida, V. D. S. (2012). O modelo de Fama e French é aplicável no Brasil. Relatórios Coppead, 0-27.

Botosan, C. A. (1997). Disclosure level and the cost of equity capital. Accounting review, 323-349.

Caldeira, J. F., Moura, G. V., \& Santos, A. A. (2013). Seleção de carteiras utilizando o modelo Fama-French-Carhart. Revista Brasileira de Economia, 67(1), 45-65.

Chan, K., Chan, L., Jegadeesh, N., \& Lakonishok, J. (2001). Earnings quality and stock returns: The evidence from accruals, University of Illinois at Urbana-Champaign. Working paper.

Chen, L. H., Dhaliwal, D. S., \& Trombley, M. A. (2008). The effect of fundamental risk on 
the market pricing of accruals quality. Journal of Accounting, Auditing \& Finance, 23(4), 471-492.

Cooper, M. J., Gulen, H., \& Schill, M. J. (2008). Asset growth and the cross-section of stock returns. The Journal of Finance, 63(4), 1609-1651.

Core, J. E., Guay, W. R., \& Verdi, R. (2008). Is accruals quality a priced risk factor? Journal of Accounting and Economics, 46(1), 2-22.

Cupertino, C. M., Martinez, A. L., \& Costa Jr, N. C. A. D. (2012). Accrual anomaly in the Brazilian capital market. BAR-Brazilian Administration Review, 9(4), 421-440.

Dechow, P. M., Hutton, A. P., Kim, J. H., \& Sloan, R. G. (2012). Detecting earnings management: A new approach. Journal of Accounting Research, 50(2), 275-334.

Easley, D., \& O'hara, M. (2004). Information and the cost of capital. The journal of finance, 59(4), 1553-1583.

Easley, D., Hvidkjaer, S., \& O’Hara, M. (2002). Is information risk a determinant of asset returns? The journal of finance, 57(5), 2185-2221.

Fama, E. F. (1970). Efficient capital markets: A review of theory and empirical work. The journal of Finance, 25(2), 383-417.

Fama, E. F. (1991). Efficient capital markets: II. The journal of Finance, 46(5), 1575-1617.

Fama, E. F., \& French, K. R. (2008). Dissecting anomalies. The Journal of Finance, 63(4), 16531678 .

Fama, E. F.; French, K. R. (2015) A fivefactor asset pricing model. Journal of Financial Economics, 116(1), 1-22.

Fields, T. D., Lys, T. Z., \& Vincent, L. (2001). Empirical research on accounting choice. Journal of accounting and economics, 31(1), 255-307.
Francis, J., LaFond, R., Olsson, P., \& Schipper, K. (2005). The market pricing of accruals quality. Journal of accounting and economics, 39(2), 295-327.

Gray, P., Koh, P. S., \& Tong, Y. H. (2009). Accruals quality, information risk and cost of capital: Evidence from Australia. Journal of Business Finance \& Accounting, 36(1-2), 51-72.

Gujarati, D. N. (2011). Econometria Básica. Rio de Janeiro: Elsevier.

Haw, I. M., Ho, S. S., \& Li, A. Y. (2011). Corporate governance and earnings management by classification shifting. Contemporary Accounting Research, 28(2), 517-553.

Hirshleifer, D., Hou, K., \& Teoh, S. H. (2012). The accrual anomaly: risk or mispricing? Management Science, 58(2), 320-335.

Jones, J. J. (1991). Earnings management during import relief investigations. Journal of accounting research, 193-228.

Kaserer, C., \& Klingler, C. (2008). The accrual anomaly under different accounting standards-lessons learned from the German experiment. Journal of Business Finance \& Accounting, 35(7-8), 837-859.

Khan, M. (2008). Are accruals mispriced? Evidence from tests of an intertemporal capital asset pricing model. Journal of Accounting and Economics, 45(1), 55-77.

Kim, D., \& Qi, Y. (2010). Accruals quality, stock returns, and macroeconomic conditions. The Accounting Review, 85(3), 937-978.

Kim, Y. J., Kim, J. H., Kwon, S., \& Lee, S. J. (2015). Percent accruals and the accrual anomaly: Korean evidence. Pacific-Basin Finance Journal, 35, 340-366.

LaFond, R. (2005). Is the accrual anomaly a global anomaly? SSRN working paper. 
Lambert, R., Leuz, C., \& Verrecchia, R. E. (2007). Accounting information, disclosure, and the cost of capital. Journal of accounting research, 45(2), 385-420.

Liu, W. (2006). A liquidity-augmented capital asset pricing model. Journal of financial Economics, 82(3), 631-671.

Lopes, A. B.; Walker, M. (2008) Firm-level incentives and the informativeness of accounting reports: an experiment in Brazil. SSRN working paper.

Machado, M. A. V., \& Faff, R. W. (2018). Asset growth and stock return: evidence in the Brazilian market. Revista Contabilidade \& Finanças, (AHEAD).

Machado, M. A. V., \& Reis Machado, M. (2014). Liquidez e precificação de ativos: evidências do mercado brasileiro. BBR-Brazilian Business Review, 11(1).

Machado, M. A. V., Faff, R., \& Silva, S. C. D. S. (2017). Applicability of Investment and Profitability Effects in Asset Pricing Models. Revista de Administração Contemporânea, 21(6), 851-874.

Machado, M. A. V.; Medeiros, O. R. (2011). Modelos de Precificação de Ativos e o Efeito Liquidez: Evidências Empíricas no Mercado Acionário Brasileiro. Revista Brasileira de Finanças, 9(3), 383-412.

Martinez, A. L. (2001). Gerenciamento dos resultados contábeis: estudo empirico das companhias abertas brasileiras. Doctoral Thesis in Accounting, University of São Paulo, São Paulo, SP, Brazil.

Mashruwala, C. A., \& Mashruwala, S. D. (2011). The pricing of accruals quality: January versus the rest of the year. The Accounting Review, 86(4), 1349-1381.

Mashruwala, C., Rajgopal, S., \& Shevlin, T. (2006). Why is the accrual anomaly not arbitraged away? The role of idiosyncratic risk and transaction costs. Journal of Accounting and Economics, 42(1-2), 3-33.

Noda, R. F., Martelanc, R., \& Kayo, E. K. (2016). O fator de risco lucro/preço em modelos de precificação de ativos financeiros. Revista Contabilidade \& Finanças, 27(70), 67-79.

Ohlson, J. A., \& Bilinski, P. (2014). Risk versus Anomaly: A New Methodology Applied to Accruals. The Accounting Review, 90(5), $2057-$ 2077.

Ozkan, N., \& Kayali, M. M. (2015). The accrual anomaly: Evidence from Borsa Istanbul. Borsa Istanbul Review, 15(2), 115-125.

Pae, J. (2005). Expected accrual models: the impact of operating cash flows and reversals of accruals. Review of Quantitative Finance and Accounting, 24(1), 5-22.

Porta, R., Lopez-de-Silanes, F., Shleifer, A., \& Vishny, R. (2002). Investor protection and corporate valuation. The journal of finance, 57(3), 1147-1170.

Rogers, P., \& Securato, J. R. (2009). Estudo Comparativo no Mercado Brasileiro do Capital Asset Pricing Model (CAPM), Modelo 3-Fatores de Fama e French e Reward Beta Approach. RACEletrônica, 3(1).

Silva Filho, A. C., \& Machado, M. A. V. (2013). Persistência e relevância dos accruals: evidências do mercado de capitais brasileiro. Revista de Educação e Pesquisa em Contabilidade (REPeC), 7(4).

Sloan, R. (1996). Do stock prices fully reflect information in accruals and cash flows about future earnings? Accounting review, 71(3), 289315.

Takamatsu, R. T., \& Fávero, L. P. L. (2013). Accruals, Persistence of Profits and Stock Returns in Brazilian Public Companies. 
Tiniç, S. M. (1990). A perspective on the stock market's fixation on accounting numbers. The Accounting Review, 65(4), 781-796.
Xie, H. (2001). The mispricing of abnormal accruals. The accounting review, 76(3), 357-373.

\begin{abstract}
About the Authors:
1. Vinícius Gomes Martins, Doctor in Accounting, Federal university of Pernanbuco, Brazil. E-mail: viniciuscontabeis@hotmail.com
\end{abstract}

ORCIID

(iD0000-0001-7401-9570

2. Paulo Aguiar do Monte, Doctor in Economics, Federal university of Paraíba, Brazil.

E-mail: pauloaguiardomonte@gmail.com

ORCIID

(iD)0000-0001-5376-3771

3. Márcio André Veras Machado, Doctor in Finance, Federal University of Paraíba, Brazil.

E-mail: mavmachado@hotmail.com

ORCIID

(D)0000-0003-2635-5240

\title{
Contribution of each author
}

\begin{tabular}{|c|c|c|c|}
\hline Contribution & $\begin{array}{c}\text { Vinícius Gomes } \\
\text { Martins }\end{array}$ & $\begin{array}{c}\text { Paulo Aguiar } \\
\text { do Monte }\end{array}$ & $\begin{array}{c}\text { Márcio André } \\
\text { Veras Machado }\end{array}$ \\
\hline 1. Definition of research problem & $\sqrt{ }$ & $\sqrt{ }$ & $\sqrt{ }$ \\
\hline 2. Development of hypotheses or research questions (empirical studies) & $\sqrt{ }$ & & \\
\hline \multicolumn{4}{|l|}{ 3. Development of theoretical propositions (theoretical Work) } \\
\hline 4. Theoretical foundation/ Literature review & $\sqrt{ }$ & & \\
\hline 5. Definition of methodological procedures & $\sqrt{ }$ & $\sqrt{ }$ & $\sqrt{ }$ \\
\hline 6. Data collection & $\sqrt{ }$ & $\sqrt{ }$ & \\
\hline 7. Statistical analysis & $\sqrt{ }$ & $\sqrt{ }$ & $\sqrt{ }$ \\
\hline 8. Analysis and interpretation of data & $\sqrt{ }$ & $\sqrt{ }$ & $\sqrt{ }$ \\
\hline 9. Critical revision of the manuscript & $\sqrt{ }$ & $\sqrt{ }$ & $\sqrt{ }$ \\
\hline 10. Manuscript Writing & $\sqrt{ }$ & $\sqrt{ }$ & $\sqrt{ }$ \\
\hline 11. Other (please specify which) & & & \\
\hline
\end{tabular}

